\title{
ПРОЯВЛЕНИЕ МУЛЬТИКУЛЬТУРАЛИЗМА В АЗЕРБАЙДЖАНСКОМ ИСКУССТВЕ
}

\begin{abstract}
Цель статьи - рассмотреть некоторые проявления мультикультурализма в азербайджанском искусстве. Отмечается, что разные народы и этнические группы, живущие веками вместе в Азербайджане, стали основным мотивом формирования мультикультурного искусства. В связи с этим подчеркивается, что мультикультуральные, толерантные отношения разных национальностей оставили глубокий след в классической азербайджанской литературе, фольклоре, музыке, театре и изобразительном искусстве с помощью художественных и эстетических средств выражения. Мультикультурализм - это феномен, отражающий смешение множества видов искусства и культурных традиций. Как политическая философия, мультикультурализм включает в состав своей идеологии все аспекты пропаганды равного уважения к различным искусствам и культурам, до политики защиты культурного разнообразия. В этом смысле мультикультурализм напоминает "культурную мозаику». Основы мультикультурализма исходят из культуры. Так, культура - это набор управляющих принциипов, диалог в разных сегментах общества.
\end{abstract}

Методы исследования: в процессе исследования использованы такие общенаучные методы, как теоретическое обоснование, сравнительный анализ аналогов в истории формирования мультикультурализма в сфере искусства, характеристика проявления толерантности.

Новизна в исследовании проявляется в подтверждении в мультикултуральности и толерантности Азербайджана из-за наличия в стране ряда национальных меньшинств, малочисленных народов и этнических групп, в обращении повышенного внимания к социокультурной жизни этих этносов, в научно-логическом ответе на мифы об ассимиляции народов нетюркского происхождения в Азербайджане, в представлении Азербайджана как живого музея мультикультурализма и толерантности.

В заключении отмечается, что на основании анализа произведений искусства, которое ярко воплощзает богатые мультикультуральные традииии, оставившие глубокий след в художественном и эстетическом мышлении азербайджанского народа, подчеркивается, что, мультикультуральное искусство сформировалось и в Азербайджане, где веками совместно жили разные народы и этносы, и из-за этого искусство, которое отражает жизнь с помощью художественных образов, остается верныл своим традициям и воплощчает это мультикультуральное мышление и ценности. Так же отмечается, что мультикультуральные, толерантные отношения представителей разных народов оставили глубокий след в классической азербайджанской литературе, фольклоре, музыке, театре и изобразительном искусстве с помощью художественных и эстетических средств выражения.

Ключевые слова: мультикультурализм, толерантность, искусство, интернациональность, мультикультуральное искусство.

Севіндж ДАДАШЗАДЕ, orcid.org/0000-0003-0220-4675

дисертант кафедри суспільних дисииплін Азербайджанського університету туризму і менеджменту (Баку, Азербайджан)d.seva91@gmail.com

\section{ПРОЯВ МУЛЬТИКУЛЬТУРАЛІЗМУ В АЗЕРБАЙДЖАНСЬКОМУ МИСТЕЦТВІ}

Мета статmі - розглянути деякі прояви мультикультуралізму в азербайджанському мистеитві. Зазначається, щуо різні народи й етнічні групи, які живуть століттями разом в Азербайджані, стали основним мотивом формування мультикультурного мистецтвва. 3 огляду на иче наголошується, щзо мультикультуральні, толерантні відносини різних національностей залишили глибокий слід у класичній азербайджанській літературі, фольклорі, музииі, театрі та образотворчому мистеитві за допомогою художніх і естетичних засобів вираження. Мультикультуралізм - иее феномен, щь відображає змімання безлічі видів мистецтва й культурних традицій. Як політична філософія, мультикультуралізм включає до складу своєї ідеологї всі аспекти пропаганди рівної поваги до різних мистецттв і культур, до політики захисту культурного розмаїття. У изьому сенсі мультикультуралізм нагадує «культурну мозаїку». Основи мультикультуралізму виходять із культури. Так, культура - ие набір керівних принцииів, діалог у різних сегментах суспільства. 
Методи дослідження: у процесі дослідження використано такі загальнонаукові методи, як теоретичне обтрунтування, порівняльний аналіз аналогів в історії формування мультикультуралізму в сфері мистецтва, характеристика прояву толерантності.

Новизна в дослідженні проявлясться в підтвердженні мультикультуральності й толерантності Азербайджану через наявність у краӥні низки національних меншин, нечисленних народів $і$ етнічних груп, у зверненні підвищеної уваги до соичокультурного життя ичих етносів, у науково-логічній відповіді на міфи про асиміляцію народів нетюркського походження в Азербайджані, у представленні Азербайджану як живого музею мультикультуралізму й толерантності.

У висновку зазначається, щзо на підставі аналізу творів мистеитва, яке яскраво втілює багаті мультикультуральні традииї, щзо залишили глибокий слід у художньому та естетичному мисленні азербайджанського народу, наголошується, щз мультикультуральне мистецтво сформувалося $і$ в Азербайджані, де століттями спільно жили різні народи й етноси, $і$ через ие мистецтво, яке відображає життя за допомогою художніх образів, залишається вірним своїм традиціям і втілює цее мультикультуральне мислення та иінності. Так само зазначається, щуо мультикультуральні, толерантні відносини представників різних народів залишили глибокий слід у класичній азербайджанській літературі, фольклорі, музиці, театрі та образотворчому мистецтві за допомогою художніх і естетичних засобів вираження.

Ключові слова: мультикультуралізм, толерантність, мистецтво, інтернаціональність, мультикультуральне мистеитво.

Sevinj DADASHZADE, orcid.org/0000-0003-0220-4675

Dissertation Candidate at the Department of Social Disciplines Azerbaijan University of Tourism and Management (Baku,Azerbaijan)d.seva91@gmail.com

\section{THE MANIFESTATION OF MULTICULTURALISM IN AZERBAIJANI ART}

The purpose of the article is to consider some manifestations of multiculturalism in Azerbaijani art. It is noted that different peoples and ethnic groups living together for centuries in Azerbaijan have become the main motive for the formation of multicultural art. In this regard, it is emphasized that multicultural, tolerant relations of different nationalities have left a deep mark on the classical Azerbaijani literature, folklore, music, theater and visual arts with the help of artistic and aesthetic means of expression.

Multiculturalism is a phenomenon that reflects the amalgamation of many arts and cultural traditions. As a political philosophy, multiculturalism includes in its ideology all aspects of promoting equal respect for different arts and cultures, up to the policy of protecting cultural diversity. In this sense, multiculturalism resembles a "cultural mosaic". The foundations of multiculturalism come from culture. Thus, culture is a set of guiding principles for dialogue in different segments of society.

Methods of research: in the course of the research such general scientific methods as theoretical justification, comparative analysis of analogs in the history of the formation of multiculturalism in the field of art, characteristics of the manifestation of tolerance were used.

The novelty in the study is manifested in the confirmation of the multiculturalism and tolerance of Azerbaijan due to the presence in the country of a number of national minorities, small peoples and ethnic groups, in the increased attention to the socio-cultural life of these ethnic groups, in the scientific and logical response to the myths about the assimilation of peoples of non-Turkic origin in Azerbaijan, in the presentation of Azerbaijan as a living museum of multiculturalism and tolerance.

In conclusion it is noted that based on the analysis of works of art, which vividly embodies the rich multicultural traditions that have left a deep imprint on the artistic and aesthetic thinking of the Azerbaijani people. It is emphasized that multicultural art has also formed in Azerbaijan, where different peoples and ethnic groups have lived together for centuries, and because of this, art, which reflects life through artistic images, remains true to its traditions and embodies these multicultural thinking and values. It is also noted that the multicultural, tolerant relations of representatives of different peoples have left a deep imprint on the classical Azerbaijani literature, folklore, music, theater and visual arts with the help of artistic and aesthetic means of expression.

Key words: multiculturalism, tolerance, art, internationality, multicultural art.

Постановка проблемы. Одно из главных проявлений мультикультурализма, считающегося глобальным явлением, это искусство. В научных кругах данное направление характеризуется как мультикультурное искусство. Важная особенность культуры и искусства объясняется тем, что люди творчески передают свои политические, позитивные, уникальные обращения в глобальном масштабе, независимо от их этнического состава, расы или места проживания. С этим аспектом связан другой аспект сущности «мультикультурализма», напрямую связанный с понятием «культура». В социологии мультикультурализм, заменяющийся синонимами «этнический 
плюрализм» и «культурный плюрализм», означает вступление наций в диалог друг с другом, не жертвуя своеобразностью, а также сотрудничество различных этнических групп. Мультикультурализм - это феномен, отражающий смешение множества видов искусства и культурных традиций. Как политическая философия мультикультурализм включает в состав своей идеологии все аспекты пропаганды равного уважения к различным искусствам и культурам до политики защиты культурного разнообразия. В этом смысле мультикультурализм напоминает «культурную мозаику».

Анализ исследований. Основы мультикультурализма исходят из культуры. Так, культура - это набор управляющих принципов диалог в разных сегментах общества. Это не случайно. Потому что, во-первых, сама культура формируется из диалога, укореняется, разветвляется, передается через диалог. С этой точки зрения культура - это система, открытая идеям мультикультурализма с точки зрения ее генетического кода. Более конкретно, точнее и яснее эту мысль можно выразить следующим образом: культура как система априори - в первую очередь, мультикультуральна или же культура содержит в себе понятие мультикультуральности еще до понятия «мультикультурализм» [Azərbaycan multikulturalizmi, 2016: 171].

Сегодня проводится обширный анализ происхождения и истории мультикультурализма. Как уже упоминалось выше, генетические коды этого явления уходят в глубокую древность. В этом смысле нельзя не согласиться с мнением театроведа Айдына Талыбзаде: «Идея мультикультурализма существовала всегда, но не теоретизировалась, не выражалась и жила где-то в латентной форме. С точки зрения статуса, разные культуры всегда объединялись в рамках больших империй и формировали единую, синтетическую, другими словами, магистральную культуру» [Azərbaycan multikulturalizmi, 2016: 172]. Результатом этого диалога стало появление культуры нового типа.

Главный элемент мультикультурализма - диалог. Мультикультурализм - это философия культурного существования, основанная на идее диалога. Эта культура основана на трех принципах, первый из которых - принцип мультикультурности. Мультикультурный принцип подчеркивает ценность, уникальность и особенность каждой культуры, основанной на этом фундаменте. Занимающий второе место принцип толерантности предлагает быть терпимым к идентичности и индивидуальности других культур. Третий принцип, который выражает право на самопознание, устанавливает право на культурную идентич- ность. Все это можно увидеть на примере мультикультурной культуры и искусства Азербайджана.

Культурное разнообразие и плюрализм - одно из неотъемлемых человеческих качеств азербайджанской культуры. Самая главная причина этого признание Азербайджана страной разных народов и культур с древних времен. Азербайджан - это место, где исторически разные культурные течения совершенно свободно и комфортно соприкасались друг с другом, постоянно создавая новые культурные проявления нового качества. «Благодаря своему геостратегическому положению, эта земля, сочетающая в себе различные мировоззрения, образ жизни, культурные и духовные ценности, религиозные конфессии, является одной из самых редких культурных цивилизаций в мире со своим национально-этническим составом» [Aslanova, 2007: 353]. Расположенный на стыке Запада и Востока, Европы и Азии, на «Шелковом пути», это разнообразие Азербайджана проявилось в различных областях искусства. «Из истории известно, что с древних времен географическое положение территории Азербайджана, включающее земли, где караванные пути пересекаются в разных направлениях, веками приводило к нападениям кочевых племен и народов. Месяцы, годы, столетия сменяли друг друга, близкие и далекие племена и народы с разными языками, диалектами посещали нашу страну с разными целями, многие из них, получив желаемое, возвращались на свою родину, а некоторые оставались здесь, укоренялись и смешивались с местными жителями. Эти процессы, происходящие с древних времен, на многие века определили сложный этнический состав и культурный облик Азербайджана» [Azərbaycan tarixi, 1998: 25-26]. Исходя из этого контекста, как мы уже упоминали выше, основание Азербайджана всегда было мультикультуральным, что является неоспоримым фактом. Как отметил Айдын Талыбзаде: «Азербайджанский мугам, азербайджанский ковер и азербайджанская кухня - это выражение мультикультурального диалога, если можно так сказать, это предметный результат мультикультурального бартера, активных обмен. Для того, чтобы осуществить этот обмен, надо уметь вступать в диалог, создавать диалог» [Azərbaycan multikulturalizmi, 2016: 173].

Называя разнообразное население Азербайджана «историческим памятником», профессор Гамаршах Джавадов в своей книге «Малочисленные народы и национальные меньшинства Азербайджана» писал: «Сегодня мы фактами подтверждаем наличие ряда национальных меньшинств, малочисленных народов и этнических 
групп в Азербайджане, привлекая каждого из них к исследованию, мы повышаем внимание к социокультурной жизни этих этносов. По сути, это научно-логический ответ на мифы об ассимиляции народов нетюркского происхождения в Азербайджане ... Нам также хорошо известно, что они, с исторической точки зрения, являются живым музеем. Вот почему сегодня многочисленные азербайджанцы не жалеют своей помощи в сохранении языка, религии, этнической психологии, материальной и духовной культуры, традиции малочисленных лезгинов, талышей, татов, курдов, аваров, русских и евреев, тюрок-ахысков, народов шахдагской этнической группы - одним словом, всех этнических существ, проживающих в этом районе» [Cavadov, 2000: 16].

Изложения основного материала. Мультикультуральность азербайджанского народа ярко отражается в создаваемом им искусстве. Совершив краткую экскурсию в историю искусства Азербайджана, мы можем убедиться в подлинности наших идей. Эти и подобные черты весьма заметны и имеют большое влияние в области азербайджанской литературной и художественной мысли как исторически, так и сегодня. Наглядные примеры из эпоса «Китаби-Деде Горгуд», нашей устной и письменной литературы убедительно доказывают существование мультикультуральных традиций с далекого прошлого до наших дней. Тот факт, что люди разных религий и многоэтнического происхождения живут в толерантной среде, также нашел художественное выражение в устной и письменной литературе Азербайджана. Исследователи в этом направлении приложили серьезные усилия для выявления художественных проявлений мультикультуральных идей в азербайджанской литературе. Заслуживают внимания суждения исследователя Мохсуна Нагисойлу по этому поводу. Он представляет три формы мультикультуральных идей в классической азербайджанской литературе. Они нижеследующие:

1. Имена народов, представляющих различные религии, упоминаются с уважением, и к ним выражаются чувства уважения и дружбы;

2. Выражается большое уважение и почтение к святым, представляющим другие религии, а их высокая мораль и поведение демонстрируются и поощряются;

3. Описываются бесконечные и искренние чувства любви красавицам, представляющих разные религии и народы, а страдания и боли, перенесенные на пути воссоединения с ними, выражены художественным языком [Azərbaycan multikulturalizmi, 2016: 105].
Привлекают внимание научные рассуждения Матаната Ягубгызы, исследовательницы, ведущей всесторонние исследования в этом направлении. Автор, изучающий мультикультурализм на основе фольклорных образцов народов и этносов (удинских, аварских, сахурских, ингилойских, еврейских, лезгинских и др.), проживающих в Шеки-Загатальском районе Азербайджана, впервые представляет классификацию этих образцов. Согласно данной презентации, образцы фольклора народов и этнических групп, проживающих в данной местности: 1) первоначальные образцы слов (мифические легенды, верования, времена года и обрядовые песни); 2) детально изучается мультикультурное содержание каждого из них, классифицируя их на такие жанры, как традиционные (легенды, сказки, пословицы и притчи, анекдоты, загадки, баяты и др.) [Mətanət Yaqub q1z1, 2016: 57-146]. Анализ идей и содержания верований и толкований сновидений, клятв, похвал и проклятий, обрядовых песен, являющихся образцами первоначального жанра, путем представления убедительных фактов о верованиях, религиозных идеях, традициях жителей региона, а также об их потенциале художественного мышления дает повод сделать такой вывод, что эти образцы являются продуктом совместного творчества народов и этнических групп, проживающих в регионе, как с точки зрения искусства и эстетики, так и с точки зрения идей и содержания, религии и морали. Исследователь оценивает научные выводы, полученные при изучении образцов традиционных жанров, следующим образом: «Классификация традиционных жанровых образцов - баяты, колыбельных песен, обласканий, образцов детского фольклора по тематике, содержанию и искусству, анализ оригинальных и художественных достоинств края, изучение индивидуальных, художественных особенностей позволяет раскрыть философско-исторический, логико-психологический, художественно-эстетический мир населения региона и приводит к такому выводу, что жители региона, прошедшие одни и те же исторические этапы в одном и том же пространстве, обладали одинаковым логическим и психологическим мышлением относительно одних и тех же фактов жизни» [Mətanət Yaqub q1z1, 2016: 147]. Этот аспект еще раз доказывает, что, несмотря на все свое разнообразие и колоритные различия, все произведения искусства, принадлежащие населению региона, являются неотъемлемой частью единого азербайджанского фольклора.

Среди литературных и художественных источников азербайджанского мультикультурализма следует отметить эпосы «Китаби-Деде Горгуд», 
«Асли и Керем», былину «Шейх Санан». В этих литературных и художественных источниках идеи мультикультурализма воплощены в любви людей разных религий. Почти во всех произведениях всемирно известных писателей азербайджанской классической литературы говорится о мультикультурных ценностях. Достаточно назвать имена Афзаладдина Хагани Ширвани, Муджираддина Бейлагани, Низами Гянджеви, Эйнулгузата Хамадани, Шейх Махмуда Шабустари, Имадеддина Насими, Мухаммада Физули. Среди них только поэмы Низами Гянджеви «Семь красавиц», «Искендернаме» привлекают внимание как яркий образец поэтического проявления мультикультурализма в классической азербайджанской литературе. Художественные образы народов мира, созданные великим поэтом в этих произведениях, также важны как проявление толерантности и межнациональных отношений с людьми других религий и национальностей. Женские облики из семи климатов вокруг главного героя поэмы «Семь красавиц» Бахрама имеют разные верования. Это - индийские, греческие, славянские, магрибские (западные), харезмские, китайские и тюркские красавицы. Процесс совершенствования Бахрама как личности происходит в такой мультикультурной среде, которая, конечно же, является продуктом гения Низами [Azərbaycan multikulturalizmi, 2016: 108]. В «Искендернаме» поэт мультикультуральные мысли создавал не только художественными образами выдающихся ученых античного мира, таких как Фейлагуш (Филипп), Нигамуш, Аристотель, Сократ, Платон, Гермес, Белинас, Форфириюс, Архимед. Поэт пропаганидирует свои мультикультуральные идеи на фоне походов Александра. «Цель второго визита Александра в мир - призвать все народы к истине, справедливости и передать им силу разума и знания. Во время этой поездки Александр прибывает на Севере в такую страну, которая его поражает. Все граждане этой процветающей страны имеют равные права. Здесь нет понятия господин и раб, богатый и бедный. Этой свободной и счастливой страной правят старейшины. Низами также объясняет причину такой счастливой жизни: главные лозунги здешних людей - справедливость и гуманизм, верность и преданность, а главное - великая вера и бесконечная любовь ко Всевышнему» [Azərbaycan multikulturalizmi, 2016: 109].

В творчестве Имадеддина Насими идеи мультикультурализма воплощены в человеческом факторе. Личность - это человеческий феномен. Независимо от области, в которой они живут, нации, этнического единства, религиозных убеждений, все люди на Земле должны иметь одно общее солидарность, взаимопонимание, терпимость. Это свойство - главный критерий концепции поэта «совершенный человек». Писатели новой эпохи Гусейн Джавид, Аббасгулу ага Бакиханов, Мирза Шафи Вазех, Мирза Фатали Ахундзаде воспользовались этим человеческим мультикультуральным мышлением и описали его на высоком уровне. В частности, понятие «совершенный человек» отражено в произведении «Дьявол», которое является вершиной творчества Джавида. Главный герой произведения, Ариф, молится Богу о том, чтобы все люди мира жили вместе в мире.

Музыка - одна из областей искусства, в которой проявляются идеи азербайджанского мультикультурализма. В музыкальных образцах как традиционных, так и композиторских творчеств можно говорить об уникальной форме воспевания мультикультуральных ценностей. Одним из доказательств этой идеи является «неоспоримый факт наличия арабской, индийской, персидской музыки, традиции муг-шама» [Azərbaycan multikulturalizmi, 2016: 180] в генетике мугамов, которые считаются вершиной азербайджанской классической музыки. Исследователь-ученый Айдын Талыбзаде уникальным образом интерпретирует мультикультуральную сущность мугама: «Азербайджанский мугам был задуман, создан и сохранен в виде пластинчатой антенны, настроенной на все вибрации восточной музыки: Привлек к себе восточные песни и мелодии, звуковые модуляции и, распространился по всему миру» [Azərbaycan multikulturalizmi, 2016: 180]. Представители разных народов, живущие вместе, исторически питались музыкальным фольклором азербайджанцев, принимали участие в религиозных и национальных праздниках. Из этих праздников следует упомянуть название Новруз, который отмечается в связи с приходом весны. Этот праздник с большим энтузиазмом отмечали не только азербайджанцы, но и жители других национальностей и народов, и эта традиция сохраняется до сих пор. Диссертация исследователя Байрама Гусейнли под названием «Азербайджанская народная танцевальная музыка» также затрагивает признаки мультикультурализма в национальном фольклоре, уделяет особое место известному танцу «лезгинка» [Hüseynli Bayram, 2013: 1]. Этот танец, который считается символом лезгинского народа, занимает прочное место в азербайджанской народной музыке. Лезгинка - один из самых смелых, горделивых и быстрых мужских танцев, любимый людьми разных национальностей как танец героев и исполняется с особой теплотой. 
Музыкальный фольклор азербайджанцев и проживающих в Азербайджане малочисленных народов и этнических групп входит в репертуар музыкантов и регулярно исполняется на народных торжествах, концертах и фестивалях. Помимо музыкальных образцов, принадлежащих каждой нации, музыканты также защищают музыкальные инструменты, играют на них и знакомят с ними широкую аудиторию. С этой точки зрения в Азербайджане, наряду с такими инструментами, как тар, саз, каманча, балабан, зурна, барабан, народные исполнители играли также на дутаре, танбуре, гармоне, аккордионе и др. инструментах. В настоящее время большое количество музыкальных коллективов, представляющих эту сферу в Азербайджане, действуют на уровне любительской самодеятельности. К ним относятся ансамбль лезгинского народного танца и песни «Сувар» (город Баку), ансамбль татарского культурного центра «Туган тел» (город Баку), ансамбль татарского фольклора «Хинаяхди» (Шабранский район, село Дагбилиджи), талышский фольклорный ансамбль «Авесор» (Астаринский район, село Калакос), «Шивидкатца» (Гахский район, грузины), «Сейраным» (Загатальский район, сахуры), «Трилло», «Шахнабаб», «Мел», «Гайыбулаг», «Шахдаг», «Мелодия», «Дуставал» (Гусарский район, лезгины), «Шенлик», «Сестры» (Ленкорань, Талыш).

Проявления мультикультурализма в азербайджанской музыке полностью отражены в творчестве композиторов. В операх основателя национальной профессиональной музыки Узеира Гаджибейли «Лейли и Меджнун», «Шейх Санан», «Рустам и Зохраб», «Шах Аббас и Хуршидбану», «Асли и Керем», «Харун и Лейла», «Короглу» можно увидеть различные проявления традиций мультикультурализма. Мультикультуральные особенности отражены не только в сюжете и содержании этих произведений, но и в импровизации музыкальных нот и ладов разных народов. Эта особенность наиболее ярко отражена в знаменитых балетах «Семь красавиц», «Тропою грома» и симфонических гравюрах «Дон Кихот» известного азербайджанского композитора Гара Гараева. Здесь следует отметить, что выдающаяся личность является первым композитором в азербайджанской музыкальной культуре, который обращается к музыке народов мира. «Главная особенность произведений Караева состоит в том, что проблема индивидуальной свободы, которая является важнейшей для каждого человека, заставляет мыслить всех людей, независимо от религии и языка, призывает их к единству, что является наиболее ярким примером толерантности и мультикультурализма в искусстве» [Azərbaycan multikulturalizmi, 2016: 160]. Гара Гараев продолжает мультикультурные идеи, воспетые в поэме Низами Гянджеви «Семь красавиц», художественным воплощением музыки в одноименном балете. Так, В балете национальная принадлежность красавиц, представляющих семь стран, выражена на национальном музыкальном языке этих народов. Согласно либретто, написанному Юрием Слонимским по мотивам романа Питера Генри Абрахамса, музыкальные скачки этого балета Кара Караева завораживают: проблемы чернокожих нашли убедительное выражение в азербайджанской музыке. Мультикультуральная ценность балета «Семь красавиц», созданного гением Низами-Гара Караева, объясняется тем, что он призывает людей разных культур к диалогу и единству.

Балет «Тысяча и одна ночь» другого выдающегося композитора того же периода, Фикрета Амирова, также является монументальным музыкальным произведением, имеющим большое образовательное значение из-за своего мультикультурального значения. В этом музыкальном произведении, содержание которого взято из арабских сказок, автор создал произведение искусства с интернациональным духом, используя красочные оттенки нот. Мозаичные мелодии этой музыки приглашают людей к совместному проживанию, толерантности. Среди ценных произведений, написанных в этом духе, в истории азербайджанской музыкальной культуры можно назвать всемирно известные балеты «Читра» Ниязи и «Легенда о любви» Арифа Меликова. «В целом произведения о жизни разных народов в произведениях представителей всех поколений азербайджанской композиторской школы сформировались как особая предметная область. Аспект, объединяющий все эти произведения, - это прославление высших гуманистических идей человеческой культуры в видении и чувстве азербайджанских композиторов [Azərbaycan multikulturalizmi, 2016: 161].

Театральное искусство, основанное на живом диалоге, также включает в себя мультикультуральные традиции. Как отмечает театральный критик Айдын Талыбзаде: «... сам театр - это диалог» [Azərbaycan multikulturalizmi, 2016: 173]. Кроме того, мультикультуралбность театра привлекает внимание многими аспектами. Так, с момента основания театр был вестником человеческих идей, дружбы и солидарности. Один из важнейших способов распространения и популяризации этих идей - обращение к драматургии народов мира. С другой стороны, со временем театральное искусство стало приобретать интернациональный 
характер. Это чувствуется, в частности, в динамике развития мирового театрального искусства со второй половины XX века. Так, с тех пор ряд режиссеров со всего мира вывели на сцену идею мультикультурализма, актуализировав практику сравнения представителей разных народов мира на одной сцене театра, говорящих друг с другом на разных языках. Во всяком случае, это хорошо видно уже в первые годы становления азербайджанского театра. Азербайджанская сцена превратилась в настоящий международный творческий коллективный центр, объединяющий представителей разных народов, представляющих Кавказ. Актеры других национальностей делили сцену с местными азербайджанскими актерами и выступали на азербайджанском языке. В результате этого влияния азербайджанский язык стал известен как кавказский французский. Среди актеров, сыгравших важную роль в формировании азербайджанского театра, обязательно надо отметить исторические заслуги Памфилии Танаилиди из Греции, Марзии Давудовой из астраханских турок, россиянки Евы Оленской, Аджара Ульви Раджаба, грузинки Гамар Ханум Топурии, российского режиссера Александра Александровича Туганова. Конечно, интернациональный состав творческого коллектива азербайджанского театра этим не ограничивался. Помимо русских, на сцене национального театра в разные исторические периоды работали итальянские и еврейские режиссеры, которые проделали полезную работу по воспитанию мирового театрального искусства на сцене Азербайджана. Эти факты доказывают роль разных народов в создании мультикультуральной среды в азербайджанском театральном мире. В ноябре 2019 года в проведенной в Баку программе Международной театральной конференции «Мультикультурализм и театр» в пропаганде идей дружбы и толерантности, усилении интернациональности среди народов, сохранении мира во всем мире использование мультикультуральных принципов театрального искусства стал приоритетным шагом. С целью объединения усилий людей для совместного проживания в мультикультуральной и толерантной среде сегодня и в будущем, определение векторов развития известных театров мира составлял содержание этого приоритета. Требования, вытекающие из этого документа, также распространяются на театральные коллективы, принадлежащие к этническим меньшинствам, действующим на территории Азербайджана. В этом направлении известными театрами являются Русский драматический театр имени С. Вургуна в Баку, Государственный театр кукол в Гахском районе, Лезгинский драматический театр в Гусарах, Грузинский драматический клуб при Доме культуры в селе Алибейли Гахского района (присвоено звание «Народный театр» в 1985 году). Таким образом, исторические факты доказывают, что азербайджанский театр, являющийся частью мирового театрального искусства, во время своего существования придерживался мультикультуральных традиций и что эти традиции продолжаются и сегодня. Одна из областей искусства в Азербайджане, где широко почитаются мультикультуральные ценности, изобразительное искусство. Если мы посмотрим на любой из этих видов искусства - живопись, скульптуру, декоративно-прикладное искусство, то увидим самые яркие признаки мультикультурализма и толерантности. Только то, что русские художники много работали в Азербайджане в формировании национальной школы живописи и скульптуры, следует оценивать как подтверждение наших взглядов. Необходимо упомянуть имена художников О. Шмерлинга и И. Роттера, которые работали бок о бок с выдающимся художником Азимом Азимзаде в становлении и формировании азербайджанской графики. Работы этих художников, связанные с «Молла Насреддином», независимо от национальности, считаются неотъемлемой частью мультикультурального искусства Азербайджана. Прежде всего потому, что их произведения в «Молла Насреддине» были полностью связаны с жизнью и бытом азербайджанского народа, его желаниями и стремлениями, обычаями и традициями, литературой, фольклором и, наконец, его духом, психикой, образом мышления. «Средства изображения этих художников, создаваемый ими мир образов, изображаемые ими типы и события были родными и понятными широкой публике» [Azərbaycan incəsənəti, 1992: 219]. Творчество трио Дж. Мамедгулузаде, О. Шмерлинга, И. Роттера было основано на принципах мультикультуральности в полном смысле этого слова и дало свои прекрасные плоды искусству Азербайджана. В творческой деятельности этого мультикультурального трио были свои особенности: Мирза Джалил сам руководил деятельностью художников в «Молла Насреддине», часто задавал тематику картин, помогал подбирать типовые образы и сюжеты, точно и выразительно их описывать. Первая иллюстрация Шмерлинга к девизу журнала «Молла Насреддин»: «Я здесь из-за вас, мои братья мусульмане!» смогла составить представление о масштабах программы деятельности этого органа печати. Этот аспект, безусловно, был позитивным про- 
явлением подхода художника к жизни, быту и социальной ситуации чужого ему народа с большой чуткостью, что является одним из важнейших факторов мультикультурального отношения.

Художественное выражение ценностей мультикультурализма в азербайджанской живописи смогло выразить себя больше на тематическом уровне. Творческие поездки Надира Абдуррахманова в Корею и Микаила Абдуллаева в Индию, Афганистан и Польшу носили международный характер и явились очень важным этапом в становлении мультикультурального искусства Азербайджана. Большое значение в этом отношении имели пейзажи, созданные Н.Абдуррахмановым по корейским впечатлениям, портреты граждан страны, которые посетил М. Абдуллаев в 1950-60 гг. Художественные доски «Женщины Раджастана», «Бенгальские девушки», «Мать с ребенком» и «Маленькая Чандра», проникнутые симпатией к простому народу Индии, были произведениями искусства мультикультурального значения. За эти работы художник М. Абдуллаев был удостоен Международной премии правительства Индии им. Дж. Нехру. Все это относится к периоду становления и развития профессиональной живописи. Эти факты, совпавшие с советской эпохой, в то время оценивались не как «мультикультуральные», а под термином «интернациональный», занимавшим большее место в научном обороте. Учитывая, что интернационализм лежит в основе мультикультурализма, будет справедливо сказать, что эти произведения мультикультуральны.

Принципы мультикультуральности также сыграли ключевую роль в формировании профессиональной скульптуры Азербайджана. Так, скульпторы Ю. Кейлихис, Ю. Р. Трипольская, С. Д. Эрзя, имеющие большой опыт в этой области изобразительного искусства, работали в Азербайджане в первые годы Советской власти и посвятили свое мастерство и труд подготовке национальных кадров.

Степан Дмитрович Эрзя ленинградско-мордовского происхождения, известный в Европе как искусный художник, был приглашен в 1923 году для организации факультета скульптуры Бакинского высшего художественного училища. Первый отечественный скульптор, прошедший практику в мастерской, организованной Эрзя, Зивер Мамедова сыграла большую роль в профессиональном развитии Ибрагима Гулиева. Зивер Мамедова всегда помнила мнение Эрзи: «... чтобы быть скульптором, нужно быть плотником, слесарем и кузнецом, чтобы не зависеть от рабочего» и отмечала, что мастер не жалел своих знаний для азер- байджанских студентов [Məmmədova Zivər, 2012]. Сам этот аспект следует рассматривать как показатель здоровой мультикультуральной среды в творческом и педагогическом коллективе.

Еще одним важным историческим вкладом С. Д. Эрзи в становлении мультикультурального искусства в Азербайджане является закладка первой в стране профессиональной скульптуры. Ленинградский скульптор занимался художественным оформлением здания профсоюза в Баку (ныне улица Хагани 27) и создал несколько скульптур символов рабочего класса («Тартальщик», «Кузнец», «Молотобойцы», «Бурильщики»). В настоящее время они сохраняются как первые исторические памятники. В общем, этот памятник создавался на базе интернационального коллектива. Помимо скульпторов В. Ингала и Д. Демёнова, С. Д. Эрзя вокруг себя также собрал своих азербайджанских учеников - 3. Мамедову и художника-графика А. Рзагулиева.

Выводы. Исторические факты доказывают, что формирование и становление скульптурного искусства в Азербайджане основывается на мультикультуральных традициях. Так, наряду с С. Эрзя, большую роль в формировании мультикультурального искусства сыграли Ю. И. Кейлихис, Е. П. Трипольская, П. В. Сабсай, С. Кляцкин, Ю. Захаров. Эти художники, приехавшие в Баку, чтобы заложить основы скульптуры, познакомились с национальной культурой, искусством и его основными элементами, историческими личностями, чтобы усилить реальность и жизнеспособность произведений искусства, которые они создадут. Первая статуя в Азербайджане - памятник М. А. Сабиру был воздвигнут в 1922 году в Баку скульптором Ю. И. Кейлихисом. За короткое время сквер, где был установлен памятник, получил известность как «Сад Сабира» и стал излюбленным местом отдыха бакинцев. Чтобы создать полноценный и убедительный образ своего героя, знаменитый скульптор познакомился с его личностью, образом жизни и, самое главное, с его художественным творчеством, в результате чего он смог выразить спокойную и умеренную природу поэта-сатирика. Все эти качества являются мультикультуральными аспектами творческого процесса. Невозможно создать успешное произведение, не зная особенностей чужой культуры и людей, не проявляя к ним уважения и толерантность. Хотя эта статуя из простого материала была заменена одноименной бронзовой статуей, созданной Дж. Гарягды в 1958 году, нельзя отрицать ее историческую роль в формировании мультикультурального искусства, а также в основании профессиональной скульптуры. 
П. Сабсай был одним из художников, продолживших мультикультуральные традиции в области скульптуры. Одесский скульптор, приехавший в Баку в 1926 году, до конца своей жизни жил в Баку. Наряду с подготовкой национальных скульпторов он является автором галереи скульптурных работ, которая сегодня занимает исключительное место в формировании художественного и эстетического образа Баку. Его статуя, установленная в 1930 году в небольшом саду на одной из центральных улиц Баку в честь выдающегося азербайджанского писателя и философа М. Ф. Ахундова, привлекает внимание своей художественной истощенностью и эмоциональностью. В целом следует отметить, что скульпторы-неазербайджанцы проявили большой интерес к созданию скульптурных образов азербайджанских писателей. Этот аспект следует рассматривать, прежде всего, как результат интереса этих художников к азербайджанской литературе. Создание трех статуй на балконе музея Низами авторами русского происхождения (Натаван - Ю. Трипольская, Дж. Мамедгулузаде - Ю. Захаров, Дж. Джаббарлы - С. Кляцкин) привлекательно своей символико-мультикультуральной природой.

Анализ, основанный на произведениях искусства, ярко воплощает богатые мультикультурные традиции, оставившие глубокий след в художественном и эстетическом мышлении азербайджанского народа. Мультикультуральное искусство сформировалось и в Азербайджане, где веками совместно жили разные народы и этносы. Искусство, которое отражает жизнь с помощью художественных образов, остается верным своим традициямивоплощаетмультикультуральноемышление и ценности. Мультикультурные, толерантные отношения представителей разных народов оставили глубокий след в классической азербайджанской литературе, фольклоре, музыке, театре и изобразительном искусстве с помощью художественных и эстетических средств выражения.

\section{СПИСОК ИСПОЛЬЗОВАННЫХ ИСТОЧНИКОВ}

1. Azərbaycan multikulturalizmi. Ali məktəblər üçün dərslik. Bakı, 2016. $378 \mathrm{~s}$.

2. Aslanova R. XXI əsr: Yeni mədəniyyət məkanına inteqrasiya. Bak1, "Nurlan" nəşr., 2007, 242 s.

3. Azərbaycan tarixi. Yeddi cilddə. İkinci cild (III-XIII əsrin I rübü). Bakı, "Elm" nəşr., 1998. $596 \mathrm{~s}$.

4. Cavadov Q. Azərbaycanın azsaylı xalqları və milli azlıqlar. Bakı, 2000. $439 \mathrm{~s}$.

5. Mətanət Yaqub qızı. Azərbaycan folklorunda tolerantlıq və multikulturalizm. (Şəki-Zaqatala bölgəsində yaşayan xalqların və etnik qrupların folklor örnəkləri əsasında). Monoqrafiya. Bak1, "Elm və təhsil" nə̧̧r., 2016. $184 \mathrm{~s}$.

6. Hüseynli Bayram. Azərbaycan xalq rəqs musiqisi. Azadlıq qəzeti. Bakı, 2013, 10 iyul.

7. Azərbaycan incəsənəti. Monoqrafiya. Bakı, "İ̧ı1q" nəşr., 1992. $244 \mathrm{~s}$.

8. Məmmədova Zivər. S.D. Orzinin yaradıc1lı̆̆. "Paritet”. 2012. 26-27 yanvar. S.14.

9. Azərbaycanda multikulturalizm: biblioqrafiya. Bak1, 2016. $504 \mathrm{~s}$.

\section{REFERENCES}

1. Azərbaycan multikulturalizmi (2016), Azerbaijani multiculturalism. [Textbook for universities], Ali məktəblər üçün dərslik. Bak1, 2016. $378 \mathrm{~s}$.

2. Aslanova R. (2007), Aslanova, R. [XXI century: integration into the new cultural space. Baku, "Nurlan" publishing house], XXI əsr: Yeni mədəniyyət məkanına inteqrasiya. Bak1, "Nurlan" nəşr., 2007, 242 s.

3. Azərbaycan tarixi. (1998), [History of Azerbaijan. In 7 Volumes. The II Vol. (I quarter of III-XIII centuries). Baku, "Elm" publishing house], Yeddi cilddə. İkinci cild (III-XIII əsrin I rübü). Bakı, "Elm" nəşr., 1998. $596 \mathrm{~s}$.

4. Cavadov Q. (2000), Javadov, G.[Minorities and national minorities of Azerbaijan], Baku, Azərbaycanın azsaylı xalqları və milli azlıqlar.Bakı, 2000. $439 \mathrm{~s}$.

5. Mətanət Yaqub q1zı (2016), Matanat Yagub gizi. [Tolerance and multiculturalism in Azerbaijani folklore. (Based on folklore samples of peoples and ethnic groups living in Sheki-Zagatala region). Monograph. Baku, "Science and education" edition], Azərbaycan folklorunda tolerantlıq və multikulturalizm. (Şəki-Zaqatala bölgəsində yaşayan xalqların və etnik qrupların folklor örnəkləri əsasında). Monoqrafiya. Bakı, "Elm və təhsil" nəşr., 2016. $184 \mathrm{s.}$

6. Hüseynli, Bayram (2013), Huseynli, Bayram [Azerbaijani folk dance music. Azadlig newspaper], Azərbaycan xalq rəqs musiqisi. Azadlıq qəzeti. Bakı, 10 iyul.

7. Azərbaycan incəsənəti (1992), Azerbaijani art. [Monograph. Baku, "Ishiq" publishing house], Monoqrafiya. Bak1, "İşı" nəşr., $244 \mathrm{~s}$.

8. Məmmədova Zivər (2012), Mammadova Zievar, [S.D. Erzs art supply newspaper "Paritet"], Paritet" qəzeti, 26-27 yanvar. S. 14. Azərbaycanda multikulturalizm (2016), Multiculturalism in Azerbaijan [Bibliography. Baku], Biblioqrafiya, Bak1, 2016. $504 \mathrm{~s}$. 